\title{
In memory of Torgny Vinje-a genuine polar scientist
}

\author{
Elisabeth Isaksson, Sebastian Gerland \& Dmitry Divine \\ Norwegian Polar Institute, Fram Centre, PO Box 6606 Langnes, NO-9296 Tromsø, Norway
}

Torgny Vinje, one of the most important polar scientists in Norway during the "modern polar era," passed away on 23 September 2015. Vinje worked for the Norwegian Polar Institute (NPI) for 40 years and for many years led its geophysics group. He was born in Mandal, in southern Norway, in 1929. In 1956, shortly after receiving his candidatus realium degree in meteorology at the University of Oslo, he left for his first Antarctic expedition, which was also his first assignment for the NPI. The Norwegian contribution to the International Geophysical Year 1957-58 was Norway Station, established about $35 \mathrm{~km}$ from the coast line on Princess Märtha Coast in Dronning Maud Land. One of 14 overwintering men, Vinje served as a meteorologist at the main base. Vinje was among those who decided to stay when the Norway Station programme, originally planned for two years, was extended for a further year.

Among the diverse geophysical and meteorological field investigations performed, important tasks included regular meteorological observations as well as occasional measurements of ozone, earth magnetism and tides (Fig. 1). Geological and glaciological studies, as well as photography of the aurora australis with a special camera that captured images of half the celestial sphere, were carried out too. During the 1958/59 summer season an additional 12 people came to Norway Station to map parts of Dronning Maud Land. Large areas-between $70^{\circ} \mathrm{S}$ and $74^{\circ} \mathrm{S}$ and from 0 meridian to $15^{\circ} \mathrm{E}$-were surveyed from the air. Most of these measurements were ground-breaking at the time and remain valuable for modern Antarctic science. In recognition of his substantial contribution to the Norway Station programme, a glacier-Vinjebreenand a nunatak - Torgnyskjeret - in the Orvinfjella mountains of Dronning Maud Land were named after him. Vinje returned to Antarctica twice in the 1960s-70s, leading the scientific activities at Bouvetøya-one of the most isolated places on the planet-in 1978/79.

Having very broad scientific expertise and interests, Vinje worked with both terrestrial and marine research. In the 1960 s he initiated a sea-ice thickness monitoring programme at the island of Hopen in the Barents Sea. This resulting data time series, which is ongoing, is one of

\section{Correspondence}

Elisabeth Isaksson, Norwegian Polar Institute, Fram Centre, PO Box 6606 Langnes, NO-9296 Tromsø, Norway. E-mail: isaksson@npolar.no the longest of its type for Arctic sea ice (Gerland et al. 2008) and is considered one of the NPI's significant scientific assets.

In 1968, despite the progressing Cold War and difficulties in conducting collaborative Arctic research with Soviet colleagues, Vinje visited the Soviet Union and the drifting ice station North Pole 18, something that was unique for Western scientists at that time. Vinje's persistent efforts resulted, in the late 1980s, in the Soviet-Norwegian Oceanographic Programme, a major oceanographic research programme focused on the Barents Sea. A project leader representing the Norwegian side, he also took part as a field scientist, participating in a number of joint cruises onboard Norwegian and Soviet/Russian research vessels during 1988-1992.

In 1981, the NPI took over the research vessel Lance and Vinje participated in a project which included the first hydrographic transects across Fram Strait, the area between Svalbard and Greenland. Various measurements were undertaken, including investigating sea-ice thickness and physical properties of sea ice year around. These surveys laid a foundation for another long-term monitoring project, which is still going on (Vinje et al. 1998; Vinje 2001a). The outcome of this monitoring project is a long time series of sea-ice thickness, documenting the thinning of sea ice in the Arctic over the past decades (Hansen et al. 2013). Vinje also made important contributions to studies of sea-ice drift during the numerous cruises in which he participated (e.g., Vinje \& Kvambekk 1991).

In his later career, starting in the late 1980s, Vinje mapped the extent and conditions of sea ice around Svalbard (Vinje et al. 1998), work that was later expanded to the entire Nordic seas. In this project he digitized and analysed historical observations from sealing and whaling ships. That sea ice was receding was already evident from satellite observations when he started this work. Analysis of the historical sources showed for the first time that sea ice in the European Arctic had been declining since the mid-1800s (Fig. 2). The evidence of pronounced pre-1950s climate changes highlighted the problem of disentangling the roles of natural climate variability and anthropogenic forcing in the present day global warming. Vinje continued working with the historical sea-ice records after he retired from the NPI in 1999. His compilations of historical sources on past sea-ice variability became a major contribution to 


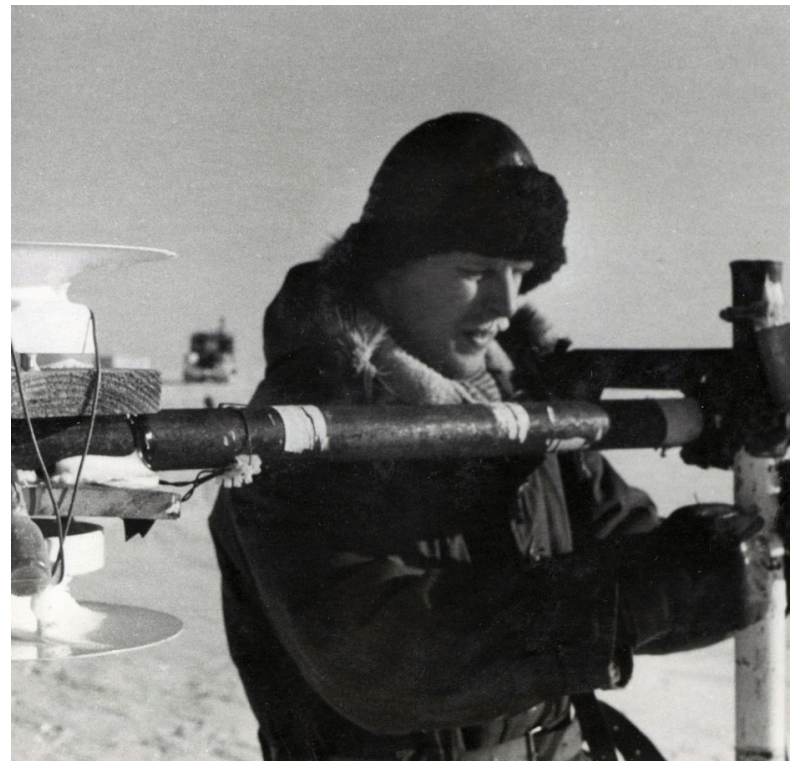

Fig. 1 Torgny Vinje with meteorological instruments during the Norway Station expedition. (Photo by Astor Ernstsen/Norwegian Polar Institute.)

the Historical Ice Chart Archive published in 2003 in the framework of the Arctic Climate System Study, under the umbrella of the World Climate Research Programme. In 2001 he published a seminal paper in the Journal of Climate in which he summarized his research on historical ice charts, with a focus on sea-ice observations in the Nordic seas back to 1853 (Vinje 200 lb). Because this publication coincided with the dramatic changes in the Arctic sea ice that were then being documented, Vinje's work received a great deal of attention in the scientific community and is still cited. The data set is much used by new generations of polar scientists working with sea ice, oceanography, paleoclimate and modelling in Norway and internationally (e.g., Divine \& Dick 2006; Macias-Fauria et al. 2009; Miles et al. 2014).

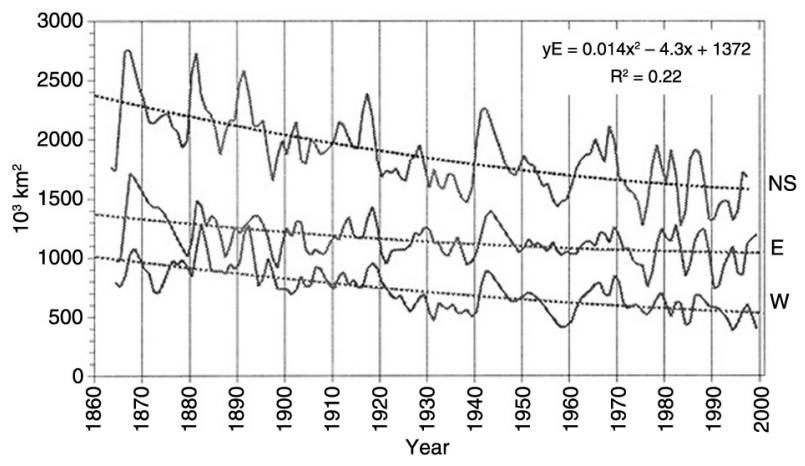

Fig. 2 April sea-ice extent in the Nordic seas (NS), and its eastern (E) and western (W) sectors, reconstructed from historical observations; dotted lines show the trends. (Adapted from Vinje 2001b. CAmerican Meteorological Society. With permission.)
In addition to being an inspiration for younger colleagues, Torgny Vinje will be remembered as a major figure in Norwegian polar research and for his central role in recognizing from the earliest years the importance of long-term monitoring of sea ice and other conditions in the Arctic ocean.

\section{References}

Divine D. \& Dick C. 2006. Historical variability of sea ice edge position in the Nordic seas. Journal of Geophysical ResearchOceans 111, article no. 10.1029/2004JC002851, doi: http:// dx.doi.org/10.1029/2004JC002851

Gerland S., Renner A.H.H., Godtliebsen F., Divine D. \& Løyning T.B. 2008. Decrease of sea ice thickness at Hopen, Barents Sea, during 1966-2007. Geophysical Research Letters 35, L06501, doi: http://dx.doi.org/10.1029/2007GL032716

Hansen E., Gerland S., Granskog M.A., Pavlova O., Renner A.H.H., Haapala J., Løyning T.B. \& Tschudi M. 2013. Thinning of Arctic sea ice observed in Fram Strait: 19902011. Journal of Geophysical Research-Oceans 118, 52025221

Macias-Fauria M., Grinsted A., Helama S., Moore J., Timonen M., Martma T., Isaksson E. \& Eronen M. 2009. Unprecedented low twentieth century winter sea ice extent in the western Nordic seas since A.D. 1200. Climate Dynamics 34 781-795.

Miles M.W., Divine D.V., Furevik T., Jansen E., Moros M. \& Ogilvie A.E.J. 2014. A signal of persistent Atlantic multidecadal variability in Arctic sea ice. Geophysical Research Letters 41, 463-469.

Vinje T. 2001a. Fram Strait ice fluxes and atmospheric circulation: 1950-2000. Journal of Climate 14, 3508-3517.

Vinje T. 2001b. Anomalies and trends of sea ice extent and atmospheric circulation in the Nordic seas during 1864 1998. Journal of Climate 14, 255-267.

Vinje T. \& Kvambekk Å.S. 1991. Barents Sea drift ice characteristics. Polar Research 10, 59-68.

Vinje T., Nordlund N. \& Kvambekk A. 1998. Monitoring ice thickness in Fram Strait. Journal of Geophysical ResearchOceans 103, 10437-10449. 